\title{
Message from the editor: welcome to the 10th volume of Immunotherapy
}

\author{
Sonia Mannan ${ }^{*}, 1$ \\ ${ }^{1}$ Future Science Group, Unitec House, 2 Albert Place, London N31QB, UK \\ * Author for correspondence: scm1392@gmail.com
}
"Aside from an increase in readership in North America, there has also been a noticeable increase in readers from other parts of the world, including Australia and South America. Immunotherapy looks forward to broadening its global reach and appeal in the coming year."”

First draft submitted: 2 November 2017; Accepted for publication: 2 November 2017; Published online: 1 December 2017

Keywords: allergen immunotherapy $\bullet$ autoimmune diseases $\bullet$ cancer immunotherapy $\bullet$ cancer vaccines $\bullet$ checkpoint inhibitors • immunotherapy

I would like to introduce the 10th Volume of Immunotherapy and take this opportunity to present some highlights from 2017 and provide some insight into what we have planned for the coming year.

First, I would like to thank all of our valued Editorial Board members, readers and contributors for their continued support; we very much look forward to seeing the journal progress and develop as we move into 2018.

\section{Increased impact factor}

I am delighted to inform you that this year, the journal witnessed an increase in its impact factor from 2.083 to 2.716, which is a delightful accomplishment.

\section{Most accessed articles from Volume 9}

I have compiled a list of the top ten most accessed articles from 2017 (Table 1). As this only shows a small number of our most popular articles, I encourage readers to explore the full content from the past year. I would also be delighted to hear which papers have particularly caught your attention and why.

\section{Readership demographic for 2017}

As Figure 1 illustrates, the journal continues to attract a wide and varied readership, with just over a half of our readership being represented by North America, followed by Europe and Asia. Since 2014, our readership in North America has more than doubled. This may be attributed to the surge in interest in immunotherapy and the increase in investment by pharmaceutical companies in the USA [11], following major breakthroughs in the field such as multiple US FDA-approved immunotherapies for melanoma treatment since 2011 [12].

Aside from an increase in readership in North America, there has also been a noticeable increase in readers from other parts of the world, including Australia and South America. Immunotherapy looks forward to broadening its global reach and appeal in the coming year.

\section{Themed issues}

Volume 9 featured themed issues covering emerging and increasingly established areas of immunotherapy, in order to shed light on these important areas following recent major breakthroughs in this aspect of the field:

- November: allergen immunotherapy

- December: immuno-oncology

The Allergen Immunotherapy special issue covered a range of both environmental and food allergies, where allergenspecific immunotherapies could have potential therapeutic use by reducing severity of symptoms in sufferers. (See 


\begin{tabular}{|c|c|c|c|c|}
\hline Rank & Title & Study & Volume (Issue) & Ref. \\
\hline 1 & $\begin{array}{l}\text { Neoepitopes as cancer immunotherapy targets: key challenges and } \\
\text { opportunities }\end{array}$ & Brennick CA, George MM, Corwin WL & Vol. 9, No. 4 & [1] \\
\hline 2 & $\begin{array}{l}\text { Modulation of cancer-specific immune responses by amino acid } \\
\text { degrading enzymes }\end{array}$ & $\begin{array}{l}\text { Timosenko E, Hadjinicolaou AV, } \\
\text { Cerundolo V }\end{array}$ & Vol. 9, No. 1 & [2] \\
\hline 3 & $\begin{array}{l}\text { Inflammatory arthritis due to immune checkpoint } \\
\text { inhibitors: challenges in diagnosis and treatment }\end{array}$ & Cappelli LC, Naidoo J, Bingham III CO & Vol. 9, No. 1 & [3] \\
\hline 4 & $\begin{array}{l}\text { Which checkpoint inhibitor? An embarrassment of riches for } \\
\text { bladder cancer }\end{array}$ & Gill DM, Sonpavde G, Pal SK, Agarwal N & Vol. 9, No. 6 & [4] \\
\hline 5 & $\begin{array}{l}\text { Targeted synthetic disease-modifying antirheumatic drugs in } \\
\text { spondyloarthritis }\end{array}$ & Wendling D, Prati C & Vol. 9, No. 3 & [5] \\
\hline 6 & $\begin{array}{l}\text { Prospects for immunotherapy of acute myeloid leukemia using } \gamma \delta \\
T \text { cells }\end{array}$ & Halim L, Parente-Pereira AC, Maher J & Vol. 9, No. 2 & [6] \\
\hline 7 & $\begin{array}{l}\text { Recombinant human hyaluronidase-facilitated subcutaneous } \\
\text { immunoglobulin infusion in primary immunodeficiency diseases }\end{array}$ & Wasserman RL & Vol. 9, No. 12 & [7] \\
\hline 8 & $\begin{array}{l}\text { PD-L1 expression as a predictive biomarker in advanced } \\
\text { non-small-cell lung cancer: updated survival data }\end{array}$ & $\begin{array}{l}\text { Aguiar Jr PN, De Mello RA, Hall P, } \\
\text { Tadokoro H, Lopes GdeL }\end{array}$ & Vol. 9, No. 6 & [8] \\
\hline 9 & $\begin{array}{l}\text { Prospects of combining adoptive cell immunotherapy with } \\
\text { bortezomib }\end{array}$ & Pellom Jr ST, Singhal A, Shanker A & Vol. 9, No. 4 & [9] \\
\hline 10 & $\begin{array}{l}\text { Systemic therapy for previously untreated advanced BRAF-mutated } \\
\text { melanoma: navigating a shifting landscape }\end{array}$ & Levine O, Devji T, Xie F & Vol. 9, No. 5 & [10] \\
\hline
\end{tabular}

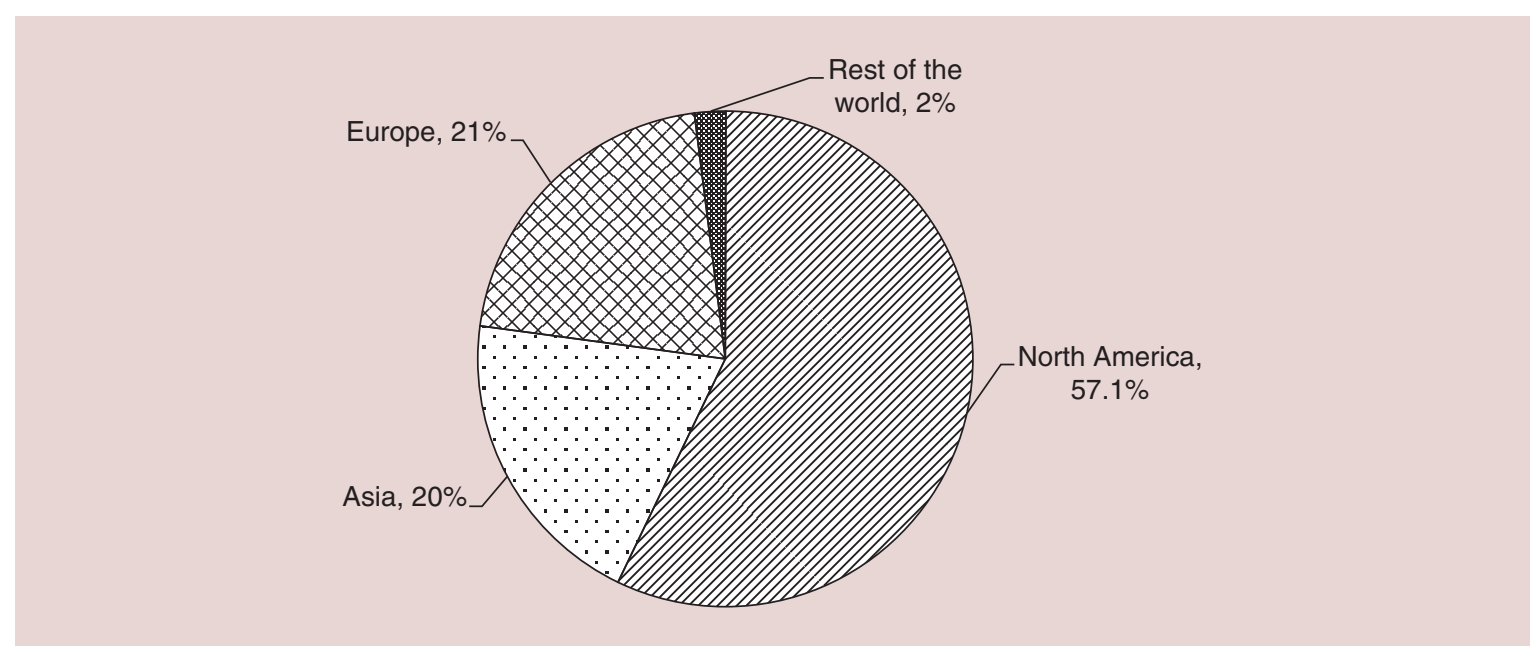

Figure 1. Readership demographics in 2017 for Immunotherapy.

Immunotherapy Volume 9, issue 15). The Immuno-oncology themed issue concluded this year's volume by exploring the latest advances in the field of cancer immunotherapy (See Immunotherapy Volume 9, issue 16).

\section{Spread the word}

The journal has been active on social media through Twitter [13] and LinkedIn [14] so as to provide regular updates on newly published content and the latest news in immunotherapy. We welcome and appreciate all contributions and feedback we receive via these platforms.

Immunotherapy is continuing its partnership with Kudos and we encourage authors to share information about their publications and monitor the impact of their efforts [15].

Immunotherapy also offers accelerated publication and open access options to our authors to increase the speed and reach of their articles. Interested readers can find out more on our website [16]. 


\section{Conclusion}

We invite and appreciate all feedback from the immunotherapy community on the direction of the field and areas you would like the journal to cover. We also welcome unsolicited article proposals, and would be delighted to hear from you. Later in 2018, we will be planning a special themed issue on immunotherapy for autoimmune diseases and would particularly welcome article proposals in this area.

Many thanks for your continuing interest and support for Immunotherapy, I look forward to working with many of you over the coming year.

\section{Financial \& competing interests disclosure}

S Mannan is an employee of Future Medicine Ltd. The author has no other relevant affiliations or financial involvement with any organization or entity with a financial interest in or financial conflict with the subject matter or materials discussed in the manuscript apart from those disclosed.

No writing assistance was utilized in the production of this manuscript.

\section{References}

1. Brennick CA, George MM, Corwin WL, Srivastava PK, Ebrahimi-Nik H. CAR T-cell therapy: opportunities and challenges. Immunotherapy 9(4), 361-371 (2017).

2. Timosenko E, Hadjinicolaou AV, Cerundolo V. Modulation of cancer-specific immune responses by amino acid degrading enzymes. Immunotherapy 9(1), 83-97 (2017).

3. Cappelli LC, Naidoo J, Bingham III CO, Ami AS. Inflammatory arthritis due to immune checkpoint inhibitors: challenges in diagnosis and treatment. Immunotherapy 9(1), 5-8 (2017).

4. Gill DM, Sonpavde G, Pal SK, Agarwal N. Which checkpoint inhibitor? An embarrassment of riches for bladder cancer. Immunotherapy 9(6), 463-466 (2017).

5. Wendling D, Prati C. Targeted synthetic disease-modifying antirheumatic drugs in spondyloarthritis. Immunotherapy 9(3), 221-223 (2017).

6. Halim L, Parente-Pereira AC, Maher J. Prospects for immunotherapy of acute myeloid leukemia using $\gamma \delta \mathrm{T}$ cells. Immunotherapy 9(2), 111-114 (2017).

7. Wasserman RL. Recombinant human hyaluronidase-facilitated subcutaneous immunoglobulin infusion in primary immunodeficiency diseases. Immunotherapy 9(12), 1035-1050 (2017).

8. Aguiar Jr PN, De Mello RA, Hall P, Tadokoro H, Lopes GdeL. PD-L1 expression as a predictive biomarker in advanced non-small-cell lung cancer: updated survival data. Immunotherapy 9(6), 499-506 (2017).

9. Pellom Jr ST, Singhal A, Shanker A. Prospects of combining adoptive cell immunotherapy with bortezomib. Immunotherapy 9(4), 305-308 (2017).

10. Levine O, Devji T, Xie F. Systemic therapy for previously untreated advanced BRAF-mutated melanoma: navigating a shifting landscape. Immunotherapy 9(5), 375-378 (2017).

11. Buffery D. The 2015 oncology drug pipeline: innovation drives the race to cure cancer. Am. Health Drug Benefits 8(4), 216-222 (2015).

12. Valpione S, Campana LG. Immunotherapy for advanced melanoma: future directions. Immunotherapy 8(2), 199-209 (2016).

13. Immunotherapy Twitter. https://twitter.com/fsgimt

14. Immunotherapy LinkedIn group. https://linkedin.com/groups/3713578

15. Kudos. www.growkudos.com/

16. Future Science Group Publishing Solutions. www.future-science-group.com/services/for-professionals/publication-solutions/ 
